\title{
Protolichesterinic Acid: A Prominent Broad Spectrum Antimicrobial Compound from the Lichen Usnea albopunctata
}

\author{
Nishanth Kumar Sasidharan, ${ }^{1}$ Sreerag Ravikumar Sreekala, ${ }^{2}$ Rajesh Lakshmanan, \\ Jubi Jacob, ${ }^{1}$ Dileep Kumar Bhaskaran Nair Saraswathy Amma, ${ }^{1}$ and Bala Nambisan ${ }^{2}$ \\ ${ }^{1}$ Agroprocessing and Natural Products Division, National Institute for Interdisciplinary Science and Technology (NIIST), \\ Council of Scientific and Industrial Research (CSIR), Thiruvananthapuram, Kerala 695019, India \\ ${ }^{2}$ Division of Crop Protection/Division of Crop Utilization, Central Tuber Crops Research Institute, Sreekariyam, \\ Thiruvananthapuram 695017, India
}

Correspondence should be addressed to Bala Nambisan; balactcri@gmail.com

Received 30 April 2014; Revised 2 June 2014; Accepted 15 July 2014; Published 10 August 2014

Academic Editor: Silvano Esposito

Copyright (C) 2014 Nishanth Kumar Sasidharan et al. This is an open access article distributed under the Creative Commons Attribution License, which permits unrestricted use, distribution, and reproduction in any medium, provided the original work is properly cited.

\begin{abstract}
The aim of this study is to investigate the antimicrobial compounds present in the lichen Usnea albopunctata. Ethyl acetate extract was purified by silica gel column chromatography to obtain a major compound and the chemical structure was characterized by ${ }^{1} \mathrm{H}-\mathrm{NMR},{ }^{13} \mathrm{C}-\mathrm{NMR}, \mathrm{DEPT},{ }^{1} \mathrm{H}-{ }^{1} \mathrm{H}$ COSY, HMQC, HMBC, UV, and HR-MS spectroscopic methods as protolichesterinic acid. The antimicrobial activity was estimated by determination of the minimal inhibitory concentration by the broth microdilution method and agar disc diffusion method against thirteen human pathogenic bacterial and four fungal strains. Protolichesterinic acid recorded significant broad spectrum antimicrobial property. The best antibacterial activity was recorded against K. pneumonia $(0.25 \mu \mathrm{g} / \mathrm{mL})$ and $V$. cholerae $(0.5 \mu \mathrm{g} / \mathrm{mL})$. Significant antifungal activity was recorded against $T$. rubrum $(0.12 \mu \mathrm{g} / \mathrm{mL})$, which is significantly better than the standard antifungal agent. Protolichesterinic acid is reported for the first time from Usnea albopunctata. Antifungal activity of protolichesterinic acid against medically important fungi is also reported for the first time. Thus the results of the present study suggest that protolichesterinic acid has significant antimicrobial activities and has the strong potential to be developed as an antimicrobial drug after further clinical evaluation.
\end{abstract}

\section{Introduction}

In recent years, both in practice and in theory, there has been great interest in new preparations of natural origin for the control and prevention of various human, animal, and plant diseases. It is known that the long-term use of synthetic drugs can cause numerous side effects and sometimes resistance [1]. Unlike synthetic drugs, bioactive natural products have beneficial effects on the whole organism. Infectious diseases are one of the world's leading causes of premature deaths [2]. Antibiotics which are widely used for the treatment of infectious diseases are under constant threat due to the emergence of antibiotic resistant pathogens such as methicillin resistant Staphylococcus aureus (MRSA), multidrug resistant Pseudomonas aeruginosa, vancomycin resistant Enterococcus
(VRE), and multidrug resistant Mycobacterium tuberculosis [2-7]. Hence, search for novel antimicrobial compounds or alternative therapy for these infections is inevitable. In the search for new bioactive preparations of natural origin, lichens are a subject of interest to many research teams.

Lichens produce secondary metabolites known as "lichen substances" and more than one thousand secondary metabolites, mainly monoaromatics, depsides, depsidones, pulvinates, dibenzofurans, anthraquinones, and xanthones, have been isolated from lichens [8]. These metabolites account for more than $30 \%$ of the dry mass of the lichen thallus. Chemical structures of these classes of compounds are almost similar and the identification is often very difficult. For a long time, some lichen species have been used in traditional medicine in the treatment of numerous infectious diseases 
[9]. Lichen substances exert a wide range of biological activities such as antibiotic, antimycotic, antiviral, antiinflammatory, analgesic, antipyretic, antiproliferative, and cytotoxic effects [10-12]. Due to a relatively recent resurgence in lichen bioactivity, the therapeutic potential of many classes of lichen metabolites in medicine has largely remained unexplored. Thus, the aim of the present work was to perform the detailed antimicrobial activities of a lichen compound isolated from Usnea albopunctata against human pathogenic microorganisms.

\section{Materials and Methods}

2.1. Chemicals and Media. All the chemicals used for extraction and purification were from Merck Limited, Mumbai, India. Silica gel (230-400 mesh) used for column chromatography and precoated silica gel $60 \mathrm{GF}_{254}$ plates used for thin layer chromatography (TLC) were from Merck Limited, Germany. Microbiological media used in the present study were from Hi-Media Laboratories Limited, Mumbai, India. All other chemicals used in this study were of the highest purity. The standard antibiotics ciprofloxacin and amphotericin B were purchased from Sigma-Aldrich (USA). The software used for the chemical structure drawing was Chemsketch Ultra, Toronto, Canada.

2.2. Lichen Samples. Lichen samples $U$. albopunctata were collected from Trivandrum, Kerala, in the September of 2012. The demonstration samples are preserved in facilities of the Crop protection Division, CTCRI, Trivandrum. Determination of the investigated lichens was accomplished using standard methods.

2.3. Preparation of the Lichen Extracts. Finely dry ground thalli of the investigated lichens $(50 \mathrm{~g})$ were extracted using acetone: methanol $(1: 1)$ in a Soxhlet apparatus. The extracts were filtered and then concentrated under reduced pressure in a rotary evaporator. The dry extracts were stored at $-18^{\circ} \mathrm{C}$ until they were used in the tests. The extracts were dissolved in 5\% dimethyl sulfoxide (DMSO) for the experiments.

2.4. The Isolation of Protolichesterinic Acid from the Lichen. The dried extract of the lichen U. albopunctata $(500 \mathrm{mg})$ was dissolved in ethyl acetate. After filtration, the residue was fractioned on a silica gel 60 column (230-400 mesh). The column was eluted with methanol-ethyl acetate gradient solvent $(10: 1$ and $5: 1)$ yielding five fractions. The fourth eluted fraction of the lichen extract contained protolichesterinic acid $(34 \mathrm{mg})$. This compound was used for structure identification and determination of the antimicrobial activities. For experiments, protolichesterinic acid was dissolved in 5\% DMSO and stored at $4^{\circ} \mathrm{C}$ for further studies.

2.5. Structural Elucidation of Protolichesterinic Acid. UVvisible spectrum of the pure compound was recorded using a Systronics double beam spectrophotometer 2201, India, at room temperature (scanning range $200-800 \mathrm{~nm}$ ). The structure of the compound was determined using nuclear magnetic resonance (NMR) spectroscopy (Bruker DRX 500 NMR instrument, Bruker, Rheinstetten, Germany) equipped with a $2.5 \mathrm{~mm}$ microprobe. NMR Spectrometer using $\mathrm{CDCl}_{3}$ was deployed to measure ${ }^{1} \mathrm{H}$ and ${ }^{13} \mathrm{C}$. All spectra were recorded at $23^{\circ} \mathrm{C}$. Chemical shifts are reported relative to the solvent peaks $\left(\mathrm{CDCl}_{3}:{ }^{1} \mathrm{H} \delta 7.24\right.$ and $\left.{ }^{13} \mathrm{C} \delta 77.23\right)$. HR-ESI-MS was performed on a Thermo Scientific Exactive Orbitrap LCMass Spectrometer with an electrospray ionization mode.

2.6. Pathogenic Microorganism in the Study. The following test microorganisms were used in the present study. Gram positive pathogenic bacteria: Bacillus subtilis (MTCC 2756), Bacillus cereus (MTCC 430), Staphylococcus aureus (MTCC 902), Staphylococcus epidermis (MTCC 435) and Staphylococcus simulans (MTCC 3610). Gram negative pathogenic bacteria: Escherichia coli (MTCC 2622), Klebsiella pneumonia (MTCC 109), Proteus mirabilis (MTCC 425), Proteus vulgaris (MTCC 1771), Vibrio cholera (MTCC 3905), Pseudomonas aeruginosa (MTCC 2642), and Salmonella typhi (MTCC 3216). Medically important fungi: Aspergillus flavus (MTCC 183), Candida tropicalis (MTCC 184), Candida albicans (MTCC 277), and Trichophyton rubrum (MTCC 296). rubrum (MTCC 296). All the test microorganisms were purchased from Microbial Type Culture collection Centre, IMTECH, Chandigarh, India. Methicillin-resistant Staphylococcus aureus (MRSA) was obtained from the Department of Medical Microbiology, Government Medical College Hospital, Trivandrum. The test bacteria were maintained on nutrient agar slants and test fungi were maintained on potato dextrose agar slants.

\section{Antibacterial Activity}

3.1. Minimum Inhibitory Concentration (MIC). The minimum inhibitory concentration of the compound was determined according to the method described by the Clinical and Laboratory Standards Institute [13], with some modifications. Two-fold serial dilutions of the antibiotics and lichen compound were made with Mueller Hinton broth (MHB) to give concentrations ranging from 0.12 to $1000 \mu \mathrm{g} / \mathrm{mL}$. Hundred microliters of test bacterial suspension were inoculated in each tube to give a final concentration of $1 \times 10^{5} \mathrm{CFU} / \mathrm{mL}$. The tubes were incubated for $24 \mathrm{~h}$ at $37^{\circ} \mathrm{C}$. The control tube did not have any antibiotics or test compounds but contained the test bacteria and the solvent used to dissolve the antibiotics and compounds. The growth was observed both visually and by measuring $\mathrm{OD}$ at $600 \mathrm{~nm}$. The lowest concentration of the test compound showing no visible growth was recorded as the MIC. Triplicate sets of tubes were maintained for each concentration of the test sample. Ciprofloxacin was used as a positive control.

3.2. Minimum Bactericidal Concentration (MBC). Minimum bactericidal concentration was determined according to the method of Smith-Palmer and Stewart [14]. About $100 \mu \mathrm{L}$ from the tubes not showing bacterial growth in the MIC test was serially diluted and plated on nutrient agar. The plates were 

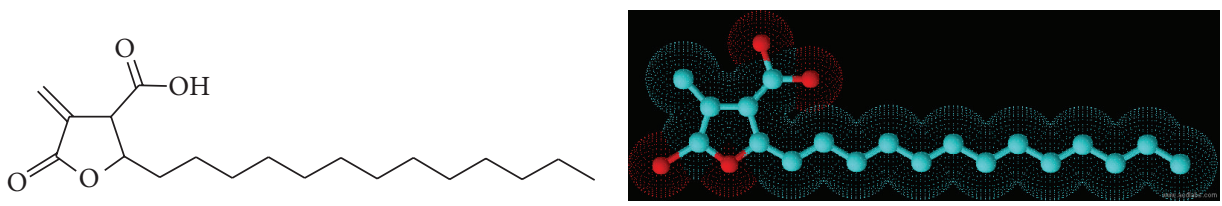

FIGURE 1: The structure of protolichesterinic acid.

incubated at $37^{\circ} \mathrm{C}$ for $24 \mathrm{~h}$. Minimum bactericidal concentration is defined as the concentration at which bacteria failed to grow on nutrient agar inoculated with $100 \mu \mathrm{L}$ test bacterial suspensions.

3.3. Antibacterial Assay by Disc Diffusion Technique. The antimicrobial activity of the pure compounds was determined by the disc diffusion method against bacteria [15]. The test cultures maintained in nutrient agar slant at $4^{\circ} \mathrm{C}$ were subcultured in nutrient broth to obtain the working cultures approximately containing $1 \times 10^{6} \mathrm{CFU} / \mathrm{mL}$. The MIC concentration of the lichen compound was incorporated in a $6 \mathrm{~mm}$ sterile disc. Mueller Hinton ( $\mathrm{MH}$ ) agar plates were swabbed with each bacterial strain and the test disks were placed along with the control disks. Ciprofloxacin disks ( $5 \mu \mathrm{g} / \mathrm{disc})$ were used as positive control. Plates were incubated overnight at $37^{\circ} \mathrm{C}$ for $24 \mathrm{~h}$. Clear, distinct zone of inhibition was visualized surrounding the discs. The antimicrobial activity of the test agents (compound and antibiotic) was determined by measuring the zone of inhibition expressed in $\mathrm{mm}$.

\section{Antifungal Assay}

4.1. Minimum Inhibitory Concentration (MIC). The MIC was performed by broth microdilution methods as per the guidelines of Clinical and Laboratory Standard Institute $[16,17]$, with RPMI 1640 medium containing L-glutamine, without sodium bicarbonate and buffered to $\mathrm{pH} 7.0$ (both from Sigma). Two-fold serial dilutions of the test compound were prepared in media in amounts of $100 \mu \mathrm{L}$ per well in 96-well microtiter plates (Tarson, Mumbai, India). The test fungal suspensions were further diluted in media, and a $100 \mu \mathrm{L}$ volume of this diluted inoculum was added to each well of the plate, resulting in a final inoculum of $0.5 \times 10^{4}$ to $2.5 \times 10^{4} \mathrm{CFU} / \mathrm{mL}$ for Candida species and $0.4 \times 10^{4}$ to $5 \times 10^{4} \mathrm{CFU} / \mathrm{mL}$ for other fungi. The final concentration of lichen compound ranged from 1 to $1000 \mu \mathrm{g} / \mathrm{mL}$. The medium without the agents was used as a growth control and the blank control used contained only the medium. Amphotericin B served as the standard drug controls. The microtiter plates were incubated at $35^{\circ} \mathrm{C}$ for $48 \mathrm{~h}$ for Candida species and $30^{\circ} \mathrm{C}$ for $72 \mathrm{~h}$ for other fungi. The plates were read using ELISA, and the MIC was defined as the lowest concentration of the antifungal agents that prevented visible growth with respect to the growth control.

4.2. Antifungal Assay by Disc Diffusion Technique. Compound was screened for their antifungal activity against test fungi by disc diffusion method $[18,19]$. The fungal cultures were grown on potato dextrose broth. The mycelium mat of fungi of 7-day old culture was suspended in normal saline solution and test inoculum was adjusted to $5 \times$ $10^{5} \mathrm{CFU} / \mathrm{mL}$. Inocula $(0.1 \mathrm{~mL})$ were applied on the surface of the potato dextrose agar plate and spread by using a cotton swab. Subsequently, filter paper discs $(6 \mathrm{~mm}$ in diameter, $\mathrm{Hi}-$ media) containing MIC concentrations of test compound was placed on the agar plates and incubated at $35^{\circ} \mathrm{C}$ for $24-$ $48 \mathrm{~h}$. Afterwards, the diameter of the inhibition zone was measured.

\section{Results}

U. albopunctata was collected from Trivandrum; Kerala was dried at room temperature and extracted with ethyl acetate. The extract after removal of solvent was screened for $B$. subtilis which was selected as initial test organism and extract recorded significant activity against this organism. The major chemical constituent was isolated by column chromatography and identified based on the spectral data; the compound was identified as tetrahydro-4-methylene-5-oxo-2-tridecyl3-furancarboxylicacid (protolichesterinic acid) (Figure 1).

5.1. Protolichesterinic Acid. ${ }^{1}$ HNMR: UV-Vis- $276 \mathrm{~nm}$, $\left(\mathrm{CDCl}_{3}\right) \delta: 11.0(\mathrm{~s}, 1 \mathrm{H}), 6.43(\mathrm{~d}, 1 \mathrm{H}, J=2.85 \mathrm{~Hz}), 6.03$ $(\mathrm{d}, 1 \mathrm{H}, J=2.85 \mathrm{~Hz}), 4.81(\mathrm{q}, 1 \mathrm{H}, J=5.5 ; 5.6 \mathrm{~Hz}), 1.68(\mathrm{~m}$, $2 \mathrm{H}, 1 \mathrm{H}, J=5.4 ; 2.7 \mathrm{~Hz}), 1.3-1.2(\mathrm{~m}, 22 \mathrm{H}), 0.89(\mathrm{t}, 3 \mathrm{H}, J=$ $5.9 \mathrm{~Hz}) .{ }^{13} \mathrm{CNMR}:\left(\mathrm{CDCl}_{3}\right) \delta: 173.8(\mathrm{CO}, \mathrm{C}-1), 163.1(\mathrm{CO}$, C-4), 132.3 (C-3), $125.9\left(\mathrm{CH}_{2}, \mathrm{C}-1\right), 78.8$ (CH, C-5), 49.4 (CH, C-2), $35.7\left(\mathrm{CH}_{2}, \mathrm{C}-12\right), 31.9(\mathrm{CH} 2, \mathrm{C}-11), 29.7,29.6$, 29.6, 29.5, 29.4, 29.4, 29.0, 29.2, 24.7, 22.7 (CH2, C-2' $\left.-\mathrm{C}-10^{\prime}\right)$ and $14.2\left(\mathrm{CH} 3, \mathrm{C}-14^{\prime}\right)$. HR-ESI-MS: $m / z 323.22391[\mathrm{M}-\mathrm{H}]+$ calculated for $\mathrm{C}_{19} \mathrm{H}_{31} \mathrm{O}_{4}$ calculated for $\mathrm{C}_{19} \mathrm{H}_{32} \mathrm{O}_{4}[\mathrm{M}+\mathrm{H}]+$.

5.2. Antibacterial Activity. The isolated protolichesterinic acid was tested for antibacterial activity against thirteen bacterial strains using standard methods. MIC and MBC values were also determined and are shown in Table 1 . The microorganism that presented highest sensitivity towards protolichesterinic acid was K. pneumonia $(0.25 \mu \mathrm{g} / \mathrm{mL})$ and $V$. cholerae $(0.5 \mu \mathrm{g} / \mathrm{mL})$. The disc diffusion result also recorded significant activity against K. pneumonia, V. cholera, S. typhi, and $P$. vulgaris (Table 1 and Figure 2). Protolichesterinic acid also recorded good activity against methicillin resistant S. aureus $(8 \mu \mathrm{g} / \mathrm{mL})$. But the activity of protolichesterinic acid against $K$. pneumonia, V. cholera, and P. vulgaris was significantly better than ciprofloxacin (Table 1). S. simulans recorded no activity.

5.3. Antifungal Activity. Antifungal activity against four fungi and corresponding MIC values is indicated in Table 1. 
TABLE 1: Antibacterial activity of protolichesterinic acid.

\begin{tabular}{|c|c|c|c|c|c|c|}
\hline \multirow[b]{2}{*}{ Test bacteria } & \multicolumn{3}{|c|}{ Protolichesterinic acid } & \multicolumn{3}{|c|}{ Ciprofloxacin } \\
\hline & $\begin{array}{c}\mathrm{MIC} \\
(\mu \mathrm{g} / \mathrm{mL})\end{array}$ & $\begin{array}{c}\mathrm{MBC} \\
(\mu \mathrm{g} / \mathrm{mL})\end{array}$ & $\begin{array}{c}\text { Diameter of zone of } \\
\text { inhibition }(\mathrm{mm})\end{array}$ & $\begin{array}{c}\text { MIC } \\
(\mu \mathrm{g} / \mathrm{mL})\end{array}$ & $\begin{array}{c}\text { MIC } \\
(\mu \mathrm{g} / \mathrm{mL})\end{array}$ & $\begin{array}{c}\text { Diameter of zone of } \\
\text { inhibition }(\mathrm{mm})\end{array}$ \\
\hline B. subtilis & 32 & 64 & 22 & 2 & 2 & 30 \\
\hline B. cereus & 64 & 64 & 21 & 1 & 2 & 31 \\
\hline S. aureus & 2 & 4 & 29 & 1 & 2 & 33 \\
\hline MR-S. aureus & 16 & 32 & 25 & 4 & 4 & 28 \\
\hline S. epidermis & 64 & 128 & 20 & 2 & 4 & 30 \\
\hline S. simulans & - & - & - & 4 & 4 & 29 \\
\hline E. coli & 8 & 8 & 30 & 1 & 2 & 27 \\
\hline P. mirabilis & 8 & 8 & 30 & 0.5 & 1 & 29 \\
\hline P. vulgaris & 2 & 4 & 31 & 2 & 4 & 30 \\
\hline V. cholerae & 0.5 & 1 & 32 & 2 & 4 & 31 \\
\hline K. pneumonia & 0.25 & 0.25 & 32 & 1 & 2 & 25 \\
\hline P. aeruginosa & 64 & 128 & 26 & 2 & 4 & 27 \\
\hline S. typhi & 4 & 8 & 27 & 4 & 4 & 29 \\
\hline
\end{tabular}

-: no activity.

TABLE 2: Antifungal activity of protolichesterinic acid.

\begin{tabular}{lcccc}
\hline Test bacteria & $\begin{array}{c}\text { PIC } \\
(\mu \mathrm{g} / \mathrm{mL})\end{array}$ & $\begin{array}{c}\text { Amphotericin B } \\
\text { Diameter of zone of inhibition }(\mathrm{mm})\end{array}$ & $\begin{array}{c}\text { MIC } \\
(\mu \mathrm{g} / \mathrm{mL})\end{array}$ & $\begin{array}{c}\text { Diameter of zone of inhibition }(\mathrm{mm}) \\
\text { A. flavus }\end{array}$ \\
C. albicans & 8 & 21 & 4 & 23 \\
C. tropicalis & 2 & 17 & 1 & 16 \\
T. rubrum & 0.12 & 24 & 1 & 19 \\
\hline
\end{tabular}

Protolichesterinic acid recorded good antifungal activity against all the tested fungi. Protolichesterinic acid exhibited best MIC value against T. rubrum $(0.12 \mu \mathrm{g} / \mathrm{mL})$. In disc diffusion assay also T. rubrum recorded significant activity (Table 2 and Figure 3 ). This activity is significantly better than the activity of amphotericin B, the standard antifungal agent.

\section{Discussion}

Natural products with diverse bioactivities and structures are an important source of novel chemicals with pharmaceutical potentials. Recently, much attention has been paid to several lichen species as resources of natural bioactive compounds. Lichens are the symbiotic products of the mycobiont (fungal partner) and photobiont (algal partner). Lichens produce a varied range of secondary metabolites and also some of them are unique to lichen symbiosis. Similarly our compound protolichesterinic acid was also unique to lichen. Protolichesterinic acid has already been reported from Cetraria islandica and Parmelia nepalensis Tayl [20]. This is the first report showing the presence of protolichesterinic acid in $U$. albopunctata.

Previously, numerous lichen compounds were screened for antimicrobial activity in search of the new antimicrobial agents [21]. In our experiments, the tested lichen compounds show very strong antimicrobial activity. Antibacterial activity was stronger than antifungal. This observation is in accordance with other studies [22], focused on the antimicrobial activity which have demonstrated that bacteria are more sensitive to the antimicrobial activity than the fungi due to differences in the composition and permeability of the cell wall. The cell wall of gram-positive bacteria is composed of peptidoglucanes and teichoic acids, while the cell wall of gram-negative bacteria is composed of peptidoglucanes, lipopolysaccharides, and lipoproteins [23]. In our study also protolichesterinic acid recorded significant activity against gram-negative bacteria.

Previously protolichesterinic acid, isolated from Iceland moss, has already been found to possess antibacterial properties against Mycobacterium tuberculosis, Streptococcus pyogenes, and Staphylococcus aureus [24]. The antifungal activity of protolichesterinic acid was reported against $P$. debaryanum and $R$. solani [25]. The antifungal activity of protolichesterinic acid against medically important fungi is not reported in literature and this is the first report of the antifungal property of protolichesterinic acid against medically important fungi.

\section{Conclusion}

The results presented in this study are the first report of protolichesterinic acid showing in vitro antifungal activity 


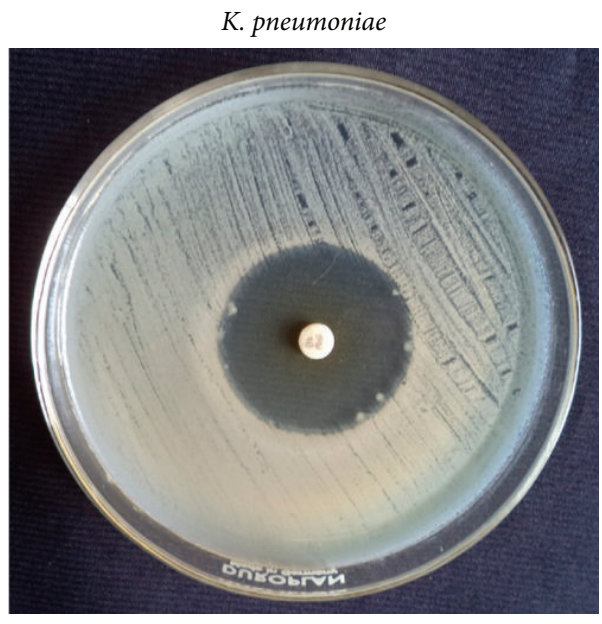

(a)

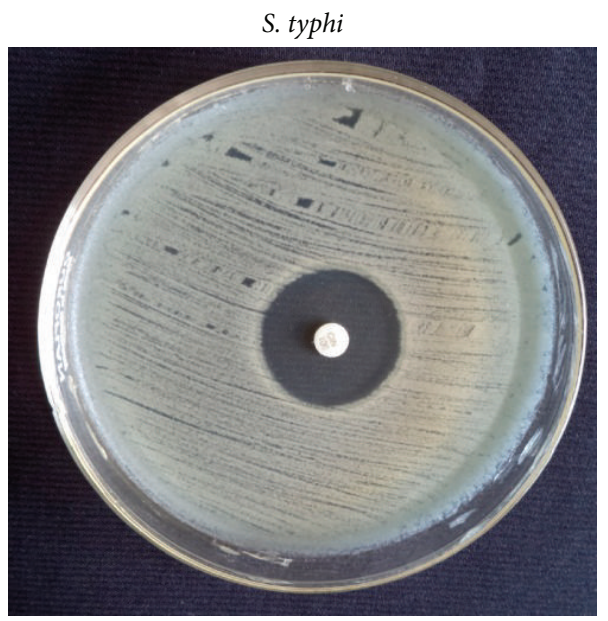

(c)

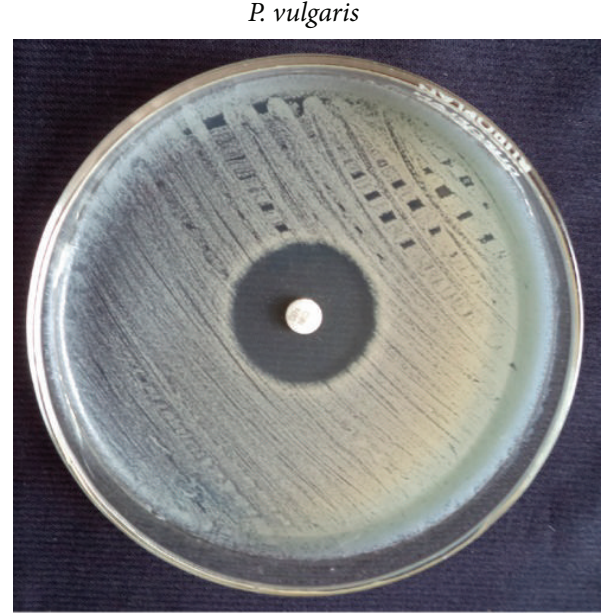

(b)

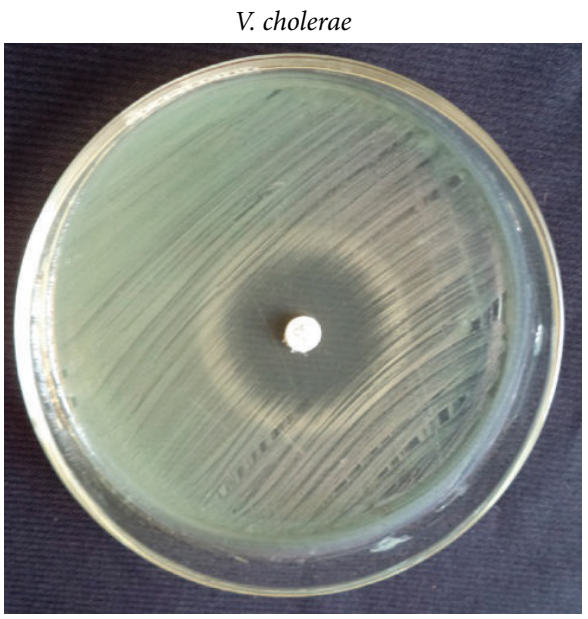

(d)

FIGURE 2: The antibacterial activity of protolichesterinic acid.

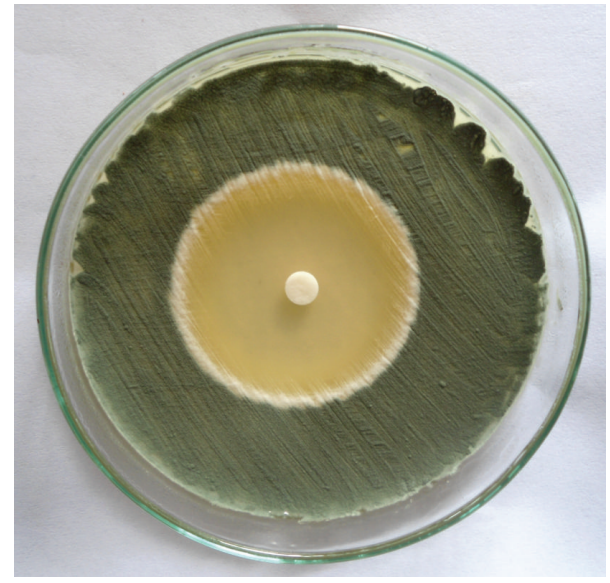

FIGURE 3: Activity of protolichesterinic acid against T. rubrum.

against medically important fungi. Considering also the absence of cytotoxicity (data not shown), protolichesterinic acid represents a promising area of future research. The mechanisms of its antimicrobial activity should be studied in order to validate the use of protolichesterinic acid as a natural antimicrobial product. Identification of more active compounds from lichens will lead to their evaluation in considerable commercial potential in pharmaceutical industry.

\section{Conflict of Interests}

The authors declare that there is no conflict of interests regarding the publication of this paper.

\section{Acknowledgments}

The authors are thankful to the Directors of CTCRI and CSIRNIIST for providing necessary facilities to carry out this work. The authors are grateful to Kerala State Council for Science Technology and Engineering (KSCSTE), Government of Kerala, for financial support. 


\section{References}

[1] I. Karaman, F. Sanin, M. Gulluce, H. Ogutcu, M. Sengul, and A. Adiguzel, "Antimicrobial activity of aqueous and methanol extracts of Juniper usoxicedrus," Journal of Ethnopharmacology, vol. 85, no. 2-3, pp. 231-235, 2003.

[2] I. Ahmad and A. Z. Beg, "Antimicrobial and phytochemical studies on 45 Indian medicinal plants against multi-drug resistant human pathogens," Journal of Ethnopharmacology, vol. 74, no. 2, pp. 113-123, 2001.

[3] R. E. Hancock, "The end of an era?" Nature Reviews Drug Discovery, vol. 6, no. 28, 2007.

[4] G. A. J. Ayliffe, W. Green, R. Livingston, and E. J. L. Lowbury, "Antibiotic resistant Staphylococcus aureus in dermatology and burn wards," Journal of Clinical Pathology, vol. 30, no. 1, pp. 4044, 1977.

[5] C. Ergin and G. Mutlu, "Clinical distribution and antibiotic resistance of Pseudomonas species," Eastern Journal of Medicine, vol. 4, no. 2, pp. 65-69, 1999.

[6] D. F. Sahm, J. Kissinger, M. S. Gilmore et al., "In vitro susceptibility studies of vancomycin-resistant Enterococcus faecalis," Antimicrobial Agents and Chemotherapy, vol. 33, no. 9, pp. 15881591, 1989.

[7] I. Devaux, K. Kremer, H. Heersma, and D. Van Soolingen, "Clusters of multidrug-resistant Mycobacterium tuberculosis cases, Europe," Emerging Infectious Diseases, vol. 15, no. 7, pp. 1052-1060, 2009.

[8] K. Molnár and E. Farkas, "Current results on biological activities of lichen secondary metabolites: a review," Zeitschrift fur Naturforschung C Journal of Biosciences, vol. 65, no. 3-4, pp. 157-173, 2010.

[9] D. Bown, Encyclopedia of Herbs and Their Uses, Dorling Kindersley, London, UK, 2001.

[10] M. Kosanić, B. Ranković, and T. Stanojković, "Antioxidant, antimicrobial, and anticancer activity of 3 Umbilicaria species," Journal of Food Science, vol. 77, no. 1, pp. T20-T25, 2012.

[11] M. Kosanic, B. Rankovic, and T. Stanojkovic, "Antioxidant, antimicrobial, and anticancer activities of three Parmelia species," Journal of the Science of Food and Agriculture, vol. 92, pp. 1909-1916, 2012.

[12] N. T. Manojlovic, P. J. Vasiljevic, W. Gritsanapan, R. Supabphol, and I. Manojlovic, "Phytochemical and antioxidant studies of Laurera benguelensis growing in Thailand," Biological Research, vol. 43, no. 2, pp. 169-176, 2010.

[13] Clinical and Laboratory Standards Institute (CLSI), Methods for Dilution Antimicrobial Susceptibility Tests for Bacteria that Grow Aerobically; Approved Standard-Ninth Edition. CLSI Documents M07-A9, Clinical and Laboratory Standards Institute, Wayne, $\mathrm{Pa}$, USA, 2012.

[14] A. Smith-Palmer and J. Stewart, "Antimicrobial properties of plant essential oils and essences against five important foodborne pathogens," Letters in Applied Microbiology, vol. 26, pp. 118-122, 1998.

[15] Clinical and Laboratory Standards Institute CLSI, "Performance standards for antimicrobial disk susceptibility tests; approved standard-eleventh edition," CLSI Documents M02A1l, Wayne, Pa, USA, 2012.

[16] Clinical and Laboratory Standards Institute (CLSI), Reference Method for Broth Dilution Antifungal Susceptibility Testing of Filamentous Fungi, as the Document is M38-A2, Clinical and Laboratory Standards Institute (CLSI), Wayne, NJ, USA, 2008.
[17] Clinical and Laboratory Standards Institute (CLSI), Reference Method for Broth Dilution Antifungal Susceptibility Testing of Yeasts, as the Document is M27-S4, Clinical and Laboratory Standards Institute (CLSI), Wayne, Pa, USA, 2012.

[18] Clinical and Laboratory Standards Institute (CLSI), Method for Antifungal Disk Diffusion Susceptibility Testing of Yeasts; Approved Guideline, M44-A2 Clinical and Laboratory Standards Institute, Wayne, Pa, USA, 2nd edition, 2009.

[19] Clinical and Laboratory Standards Institute (CLSI), "Performance standards for antifungal disk diffusion susceptibility testing of non-dermatophyte filamentous fungi; Informational supplement-First edition," CLSI Document M51-A, Clinical and Laboratory Standards Institute, Villanova, Pa, USA, 2010.

[20] A. Ö. Türk, M. Yilmaz, M. Kivanç, and H. Türk, "The Antimicrobial Activity of Extracts of the Lichen Cetraria aculeata and Its Protolichesterinic Acid Constituent," Zeitschrift fur Naturforschung C, vol. 58, no. 11-12, pp. 850-854, 2003.

[21] M. Candan, M. Yilmaz, T. Tay, M. Kivanç, and H. Türk, "Antimicrobial activity of extracts of the lichen Xanthoparmelia pokornyi and its gyrophoric and stenosporic acid constituents," Zeitschrift fur Naturforschung C: Journal of Biosciences, vol. 61, no. 5-6, pp. 319-323, 2006.

[22] M. Kosanić, N. Manojlović, S. Janković, T. Stanojković, and B. Ranković, "Evernia prunastri and Pseudoevernia furfuraceae lichens and their major metabolites as antioxidant, antimicrobial and anticancer agents," Food and Chemical Toxicology, vol. 53, pp. 112-118, 2013.

[23] N. Manojlović, B. Ranković, M. Kosanić, P. Vasiljević, and T. Stanojković, "Chemical composition of three Parmelia lichens and antioxidant, antimicrobial and cytotoxic activities of some their major metabolites," Phytomedicine, vol. 19, no. 13, pp. 1166$1172,2012$.

[24] A. Stoll, A. Brack, and J. Renz, "Die Wirkung von Flechtenstoffen auf Tuberkelbakterien und auf einige andere Mikroorganismen," Pathologie und Bakteriologie, vol. 13, no. 6, pp. 729-751, 1950.

[25] M. Goel, P. Dureja, A. Rani, P. L. Uniyal, and H. Laatsch, "Isolation, characterization and antifungal activity of major constituents of the himalayan Lichen Parmelia reticulata Tayl.," Journal of Agricultural and Food Chemistry, vol. 59, no. 6, pp. 2299-2307, 2011. 

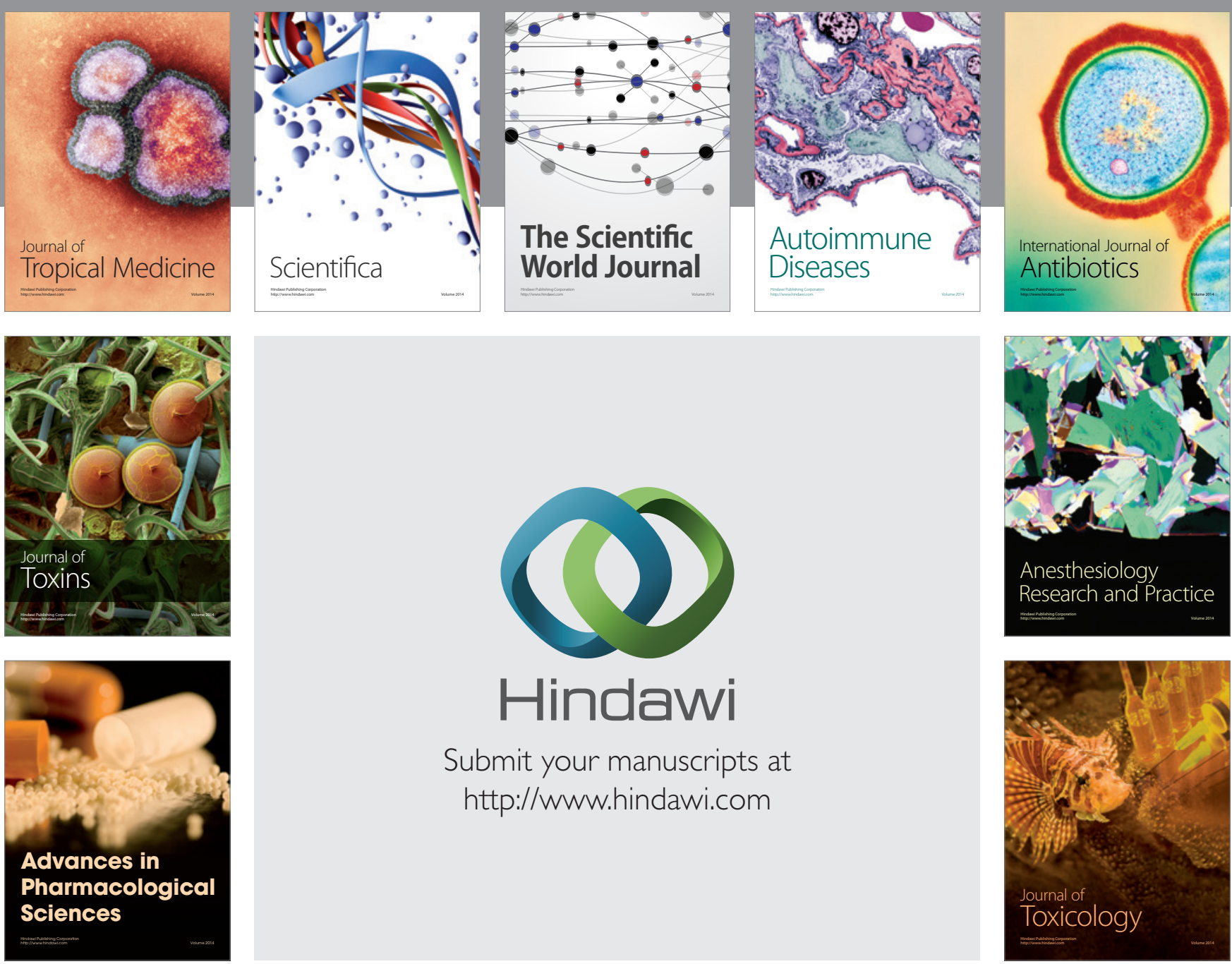

\section{Hindawi}

Submit your manuscripts at

http://www.hindawi.com
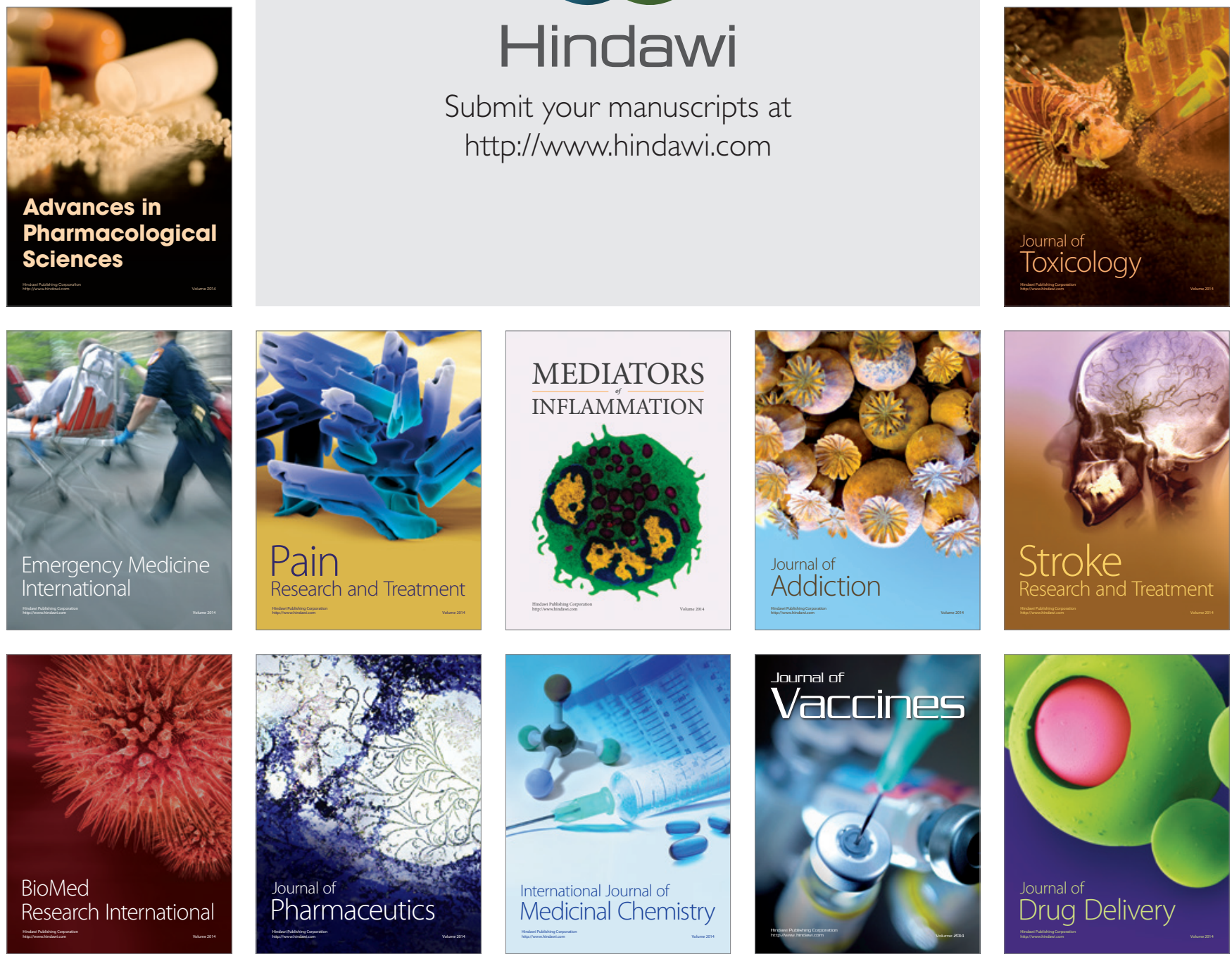